\title{
Deslocamentos no "olhar": sobre comunicação e cultura
}

\author{
Rosangela Ferreira de Carvalho Borges \\ Wellington Teixeira Lisboa
}

\section{Sobre os autores}

Rosangela Ferreira de Carvalho Borges é doutora em Ciências Sociais pela Pontifícia Universidade Católica de São Paulo (PUC/SP), com complementação pelo Instituto de Estudos Jornalísticos da Universidade de Coimbra, $e$ professora da Faculdade

de Comunicação da Fundação Armando Álvares Penteado (FAAP). rosangelafcb@yahoo.com.br

Wellington Teixeira Lisboa é doutorando em Sociologia da Universidade de São Paulo (USP) e mestre em Comunicação e Jornalismo pela Universidade de Coimbra, com diploma reconhecido no Brasil pela Escola de Comunicação e Artes da Universidade de São Paulo (ECA-USP). wtlisboa@yahoo.com.br

\section{Resumo}

Neste trabalho, objetivamos explorar os caminhos que os estudos contemporâneos das Ciências da Comunicação vêm trilhando no sentido de pensar a temática da apropriação dos textos simbólicos da mídia pelos sujeitos receptores. Incidimos, desta maneira, sobre um percurso reflexivo fundamentado nas pressuposições teóricas e metodológicas dos Estudos Culturais britânicos e latino-americanos, perspectivando quer os variados modos como os sujeitos sociais interpretam, apreendem e operam os textos midiáticos, quer o papel das mediações na salvaguarda de pontos de convergência entre os processos de codificação e decodificação discursiva.

Palauras-chave:

Comunicação, Cultura, Recepção midiática, Mediações

\section{Displacements of perspective: about communication and culture}

\section{Abstract}

In this paper we explore the ways that contemporary studies of Sciences of Communication are doing to think about the ownership of the symbolics texts of the media by subject receivers. We focus on a reflective journey based on theories and methods of British and Latin American Cultural Studies, examining the various modes such as social subjects interpret, seize and operate the texts of media and also the role of mediations in the safeguarding of convergence points between the process of encoding and decoding discursive.

Key words:

Communication, Culture, Media reception, Mediations 
As Ciências da Comunicação têm protagonizado um deslocamento nos modos de "olhar" os processos comunicativos, distanciandose de concepções apocalípticas que, por longas décadas, caracterizaram as análises empreendidas neste campo. É de conhecimento geral que, em contexto de profundas mudanças sociopolíticas e tecnológicas, coincidentes com o período da Primeira Guerra Mundial, as primeiras investigações desta área preconizavam a capacidade onipotente dos meios de comunicação massiva, identificando-os como eficazes instrumentos de manipulação social ${ }^{1}$.

Posicionado numa das extremidades desse circuito direto e linear do processo comunicativo, o receptor fora associado, naqueles estudos, a ponto final e lugar amorfo onde penetram e se disseminam os estratagemas do emissor (Nightingale, 1999; Wolf, 2006). Assim, de acordo com aquele modelo behaviorista de estímulo-resposta, o receptor não era mais que um ser alienado, indefensável e apático, ante as estratégias mercadológicas e as influências dos meios de comunicação, que não raramente eram percepcionados como esferas distintas e distantes dos contextos sócio-históricos e culturais (Brittos, 1999).

O desenvolvimento dos estudos da comunicação propiciou a adoção de novas reflexões e posturas acadêmico-intelectuais sobre as inter-relações da mídia com os sujeitos e grupos sociais, creditando a possibilidade de categorias específicas intervirem no processo comunicativo e, particularmente, no processo da recepção ${ }^{2}$. Essa viragem paradigmática nas formas de compreender a produção de textos das indústrias culturais e, sobretudo, as múltiplas maneiras como os enunciatários apropriam-se desses produtos simbólicos parece, com efeito, indicar uma saturação das doutrinas amparadas na simetria emissor/mensagem/receptor.

Na sequência à corrente teórica denominada Hipótese dos Usos e Gratificações ${ }^{3}$, os Estudos Culturais são considerados a segunda grande mudança paradigmática no que toca aos modos de "olhar" os processos comunicativos, tendo sistematizado modelos de investigação valiosos para o aprofundamento dos estudos da recepção midiática. Inaugurado por intelectuais britânicos nos anos 60 do século XX, esse campo científico transdisciplinar "objetivava investigar as formas, as práticas e as instituições culturais e as suas relações com a sociedade e com a mudança social" (Mattelart \& Mattelart, op. cit: 88). Com base nos trabalhos publicados por Richard Hoggart, Raymond Williams e Edward Thompson, autores que se debruçaram sobre as alterações dos valores tradicionais da classe operária inglesa do pós-guerra, esse movimento acadêmicointelectual instituiu o Centre for Contemporary Cultural Studies (CCCS), na Universidade de Birmingham ${ }^{4}$.

Como demonstra Polistchuk \& Trinta (2003), embora não tenha havido, no seu sentido stricto, uma continuidade dos pressupostos do paradigma crítico-radical, o modelo teórico dos Estudos Cul-
${ }^{1}$ A proposição de que os meios de comunicação atuam diretamente nos comportamentos dos sujeitos sociais aparece sistematizada, pela primeira vez, na obra de Harold D. Lasswell, intitulada Propaganda Techniques in the World War, em 1927.

Nesse trabalho, Lasswell, um dos representantes do Mass Communication Research, defende que a propaganda constitui o único meio de suscitar a adesão das massas. Este autor consagra, pois, uma visão instrumental que se coaduna ao senso comum prevalecente no pós-guerra: a derrota dos exércitos alemães deve-se, em grande medida, ao trabalho de propaganda dos Aliados (Mattelart \& Mattelart, 2002)

${ }^{2}$ Entre os estudos desenvolvidos no campo das Ciências da Comunicação tem sido frequente a expressão momento da recepção, designando a etapa em que o receptor/enunciatário se apropria do texto simbólico. No entanto, tal como Martín-Barbero (1997; 2002) e Lopes et. al. (2002), consideramos pertinente utilizar processo da recepção, por entendermos que, contrariamente a um momento estanque, circunscrito em tempo determinado, a recepção/reelaboração é, essencialmente, um processo estruturante, complexo e contínuo, que se articula a todo o ciclo comunicativo.

${ }^{3}$ Integrada aos estudos funcionalistas nos finais dos anos 60 e durante os anos 70 do século XX, a Hipótese dos Usos e Gratificações objetivava, numa primeira instância, superar as tendências behavioristas da comunicação e apresentar uma alternativa teóricometodológica frente à Teoria Crítica frankfurtiana. Simbolicamente representada 
turais revisitou e retomou muitas das reflexões exploradas pela corrente teórica frankfurtiana ${ }^{5}$. Essa rearticulação dos princípios fundamentais da Teoria Crítica lançou um viés "culturológico" à interpretação da própria cultura, apreciando suas intrínsecas confluências com as práticas sociais cotidianas, com os contextos históricos e políticos, com os dinamismos da linguagem e, também, com a representatividade simbólica dos textos midiáticos entre os distintos grupos sociais. Assim, distanciando-se de certas ortodoxias marxistas e perfilhando teses gramscianas, os estudos empreendidos pelos pesquisadores de Birmingham concebiam a cultura não apenas como um repositório de tradições, "mas um processo pelo qual se constroem significações, atualizadas e refeitas pelas ações interativas do dia-a-dia, em meio social" (Polistchuk \& Trinta, idem: 131).

Nesse sentido, a cultura afigura-se como mola propulsora do projeto dos Estudos Culturais. Ao mesmo tempo que, por um lado, esse movimento acadêmico-intelectual contesta a concepção vigente de que a cultura é exclusivamente forjada por expressões e textos literários e artísticos, assinalando, portanto, um questionamento da hierarquização entre as formas culturais, por outro lado, afirma que a cultura permeia e incorpora as experiências individuais e coletivas, os modos de vida cotidianos. É precisamente nessa acepção que Álvares \& Silveirinha (2005) referem que, adotando uma perspectiva situada no entrecruzamento dos domínios da Antropologia, da Psicanálise e da Semiótica, ou melhor, agregando pressupostos teóricos advindos de campos científicos diversificados, os Estudos Culturais incidem sobre as subjetividades e vivências, reais e/ou imaginárias, dos sujeitos sociais, explorando as narrativas tecidas e partilhadas na vida de todos os dias. A atuação das indústrias culturais, das estratégias mercadológicas, dos discursos midiáticos junto aos cotidianos simbólicos clarificam-se, pois, a partir da análise crítica e contextualizada de tais narrativas.

Stuart Hall (2003), ex-diretor do CCCS e um dos expoentes dos Estudos Culturais, atesta que a cultura não pode ser concebida apenas como uma prática cotidiana, nem tampouco como o somatório dos costumes e manifestações populares, pois "está perpassada por todas as práticas sociais e constitui a soma do inter-relacionamento das mesmas" (Hall, idem: 136). Equivale dizer que, no conceito de cultura, mesclam-se quer o conjunto de valores, significados e representações produzidos no interior dos grupos sociais - representações que, de fato, contribuem para com as (re)configurações de identidades pessoais e coletivas -, quer as práticas efetivas por meio das quais esses valores e significados se exprimem, e nas quais estão contidos (Wolf, op. cit.).

Essa perspectiva redimensiona a conceitualização de cultura para um terreno inscrito por relações de disputas de poder e por tramas de metáforas, ideologias e sentidos, ou a um espaço sim-

pelo funcionalismo de Kappler, pela pesquisa empírica de Elihu Katz, Jay Blumer e Michael Gurevitch, essa corrente de pensamento e pesquisa científica afirma que a capacidade de influência social da mídia depende de como os sujeitos operam, usam os produtos midiáticos. Sendo assim, atribui ao receptor um papel ativo no processo comunicativo, contribuindo para com as investigações no campo da comunicação social (Mattelart \& Mattelart, op. cit.; Wolf, op. cit.).

${ }^{4}$ Richard Hoggard, professor de Literatura Inglesa, funda o CCCS em 1964, com base nos resultados obtidos em sua pesquisa intitulada The Uses of Literacy (1957).

${ }^{5}$ Relativamente a esse propósito, Turner e West (2005) consideram que a retomada dos princípios marxistas pelos Estudos Culturais é mais sutil do que direta, já que este movimento acadêmico-intelectual diverge, até certo ponto, do marxismo clássico. 
bólico onde as dinâmicas do cotidiano transcorrem num movimento, difuso e complexo, de consentimentos e resistências, de legitimação, negociação e resignificação de idéias. Assim, é no âmbito da cultura, em seus pontos de tensão, fluidez e pulsão, que os textos midiáticos são articulados e (re)interpretados, tanto no que diz respeito à sua produção discursiva quanto no que concerne ao processo receptivo. A intersecção entre práticas sociais e ubiquidade de valores culturais, isto é, a cultura como dinamizadora das estruturas sociais e como força sobressaliente na construção social da realidade, desvela, logo, o posicionamento da mídia "não como causa de transformações culturais, mas como um texto onde se encontram presentes valores históricos e emergentes indicadores culturais" (Cunha, 2002: 137). Nessa linha de pensamento, as comunicações massivas são analisadas como componentes integrantes e reveladores das historicidades vigentes e da própria cultura, já que suas narrativas exploram os temores e aspirações, os conflitos e fabulações dos sujeitos e grupos com os quais interagem.

Turner \& West (op. cit.), relativamente a esse propósito, demonstram que os Estudos Culturais, embora concordem que os meios de comunicação de massa também sirvam para comunicar os pensamentos tidos como dominantes, asseguram que esses discursos são passíveis de questionamento e contestação, pois sujeitam-se aos inúmeros modos como as audiências os lêem. Nesse sentido, ainda que os dispositivos midiáticos representem uma fonte de poder nas sociedades, instituindo "lugares de fala" de grupos que buscam sua legitimação social, é o poder da ação humana (agência) que, para os teóricos dos Estudos Culturais, deve ser priorizado nos debates sobre as interações entre enunciadores e enunciatários, estratégias midiáticas e sujeitos receptores, entre mercado e cidadãos consumidores. Efetivamente, ponderam a atividade inventiva da cultura, as forças contrahegemônicas que também a constituem e a dinamizam.

\section{Codificação/Decodificação: ofícios de receptor}

As relações entre comunicação e cultura constituem problemáticabase das investigações dos Estudos Culturais. Como vimos, Hoggart, Williams e Thompson já haviam se debruçado sobre a temática da apropriação de produtos simbólicos da mídia pelos sujeitos receptores, salientando as envolvências dos contextos sócio-históricos e culturais nesse processo (McQuail, 2003; Wolf, op. cit.). Importa-nos mencionar, contudo, que muitas das análises contemporâneas acerca desse debate suportam-se, teoricamente, no modelo Codificação/Decodificação, proposto por Stuart Hall na década de 70 do século XX.

Ao refutar as abordagens defensoras de alienação cultural e de efeitos negativos das indústrias culturais sobre a cultura popular, o modelo sistematizado por Hall considera que as audiências
As comunicações massivas são analisadas como componentes integrantes e reveladores das historicidades vigentes e da própria cultura 
desempenham um duplo papel no processo comunicativo, sendo enunciatários e enunciadores do texto midiático. Essa ambivalência inerente aos ofícios dos receptores desvela, logo, uma tentativa de reposicioná-los como agentes indissociáveis dos processos de produção, circulação, consumo e apreensão dos produtos culturais (Cunha, op. cit.; McQuail, op. cit.; Turner \& West, op. cit.).

Em suas análises, Hall (op. cit.) parte das observações críticas a respeito das articulações de todas as etapas do ato comunicativo, mapeando as significações presentes tanto nas práticas de produção/enunciação quanto no contexto da recepção/reelaboração, também entendido como produção. Na produção institucional do texto midiático, por exemplo, não raramente ocorre a atribuição de valores e sentidos hegemônicos ao que se pretende circule em sociedade, tipificando um autêntico processo ideológico de codificação discursiva. No entanto, e como salienta Hall, a prática da produção textual não se esgota nos limites da concatenação de idéias e interesses do enunciador, pois tem continuidade em fases posteriores do ciclo comunicativo, como no caso da recepção do texto/discurso. Nesta etapa, o sujeito receptor, o cidadão consumidor, procede à decodificação discursiva, (re)interpretando e reelaborando os significados do texto. Experimenta, pois, uma outra trajetória de produção de discurso, reconstruindo os códigos e sentidos que lhes são ofertados e, assim, interrogando e recompondo sua própria identidade de sujeito-leitor.

Deste modo, mesmo que essa atividade mais não sirva do que para legitimar representações sociais vivificadas em temporalidades diversas, o processo receptivo desencadeia-se de forma complexa, estruturante e dialógica, não se reduzindo a uma apatia geral e a um acriticismo popular que, como mencionamos, se supunha em estudos defasados das Ciências da Comunicação. Como destaca Hall (op. cit.), a produção institucional é notoriamente relevante em todo o ciclo comunicativo, já que elege as representações que servirão de agenda pública e debate social, polarizando a atenção coletiva em torno de determinadas questões. Por outro lado, e precisamente porque as audiências são compostas por sujeitos dotados de matrizes culturais diversas, preponderantes na apropriação, ressemantização e usos diferenciados dos conteúdos das indústrias culturais, as práticas de produção e recepção não são nem coincidentes nem excludentes, mas correspondem a etapas comunicativas intrinsecamente conjugadas.

Nesse sentido, Hall (op. cit.) assinala que as leituras preferenciais, que atendem às estratégias e aos códigos emaranhados no ato da codificação do texto/discurso, também podem trilhar percursos outros, inimagináveis, e até discrepantes em relação àqueles que foram previstos, almejados. Equivale dizer que, tal como as leituras
As práticas de produção e recepção não são nem coincidentes nem excludentes, mas correspondem a etapas comunicativas intrinsecamente conjugadas 
podem simetrizar-se às ideologias e pensamentos tidos como dominantes, isto é, convergirem às leituras preferenciais sugestionadas no texto, podem também se configurar como leituras negociadas e de oposição. Sucintamente, as leituras negociadas ocorrem quando o decodificador, embora tendo apreendido os códigos estruturados no texto, readapta-os, atribuindo-lhes uma significação que vai ao encontro dos interesses pessoais articulados às historicidades socioculturais vigentes. Por sua vez, as leituras de oposição pressupõem que o decodificador reconhece o conjunto de significados codificados e questiona-os, pois são discursos em relação aos quais os sujeitos receptores mantêm estranhamentos e divergências (Hall, op. cit.).

Ante esse jogo de sentidos e leituras, o momento da hegemonia, a que se refere Hall para explanar as supostas simetrias entre codificação e decodificação, constitui um paradigma comparado a um "tipo de sonho de poder - nenhum chuvisco na tela, apenas a audiência totalmente passiva" (Hall, op. cit.: 366). Acresce que, pelo fato de não possuir apenas um único significado, o texto é essencialmente polissêmico e seus elementos constitutivos, tais como os valores ideológicos, as relações de poder e as vozes que constroem e legitimam a identidade textual, não aniquilam outras significações possíveis, outros trajetos de leitura e de interpretação/reconstrução. Interessante aludirmos que, já nos primeiros estudos de crítica literária desenvolvidos no bojo dos Estudos Culturais, defendia-se que os sentidos do texto não se encontram terminantemente inscritos nele mesmo, podendo ser negociados pelos leitores, sujeitos reais com experiências e conhecimentos para além daqueles que os textos propõem ${ }^{6}$. Assim, como sujeitos cultural e socialmente localizados, é evidente que os leitores ativam suas memórias individuais e coletivas, os imaginários e as múltiplas competências de leitura na situação de decodificação dos textos simbólicos.

As análises de Certeau (1994), no que toca aos processos de apropriação dos produtos culturais por parte dos consumidores, também confluem nessa linha de pensamento, pois este autor defende a existência de uma criação anônima, sub-reptícia, que permeia e conduz essa dinâmica interpretativa. De acordo com este autor, é preciso investigar os usos, aquilo que os cidadãos consumidores fabricam, apreendem em sua vivência cultural cotidiana, pois é nesse movimento que se estabelece um jogo de forças em que os sujeitos trapaceiam, desviam e não se conformam com a disciplina de poderes instituídos. É a arte da bricolagem, essa "atividade de formigas", que possibilita a mobilização dos receptores na economia cultural dominante, defendendo seus interesses e regras próprios, exercendo e burlando a ordem vigente.

Nessa perspectiva, e posicionando-se contrariamente a uma suposta passividade por parte dos consumidores, Certeau afirma que os cidadãos receptores são produtores desconhecidos, poetas

${ }^{6}$ No campo literário, muitos exemplos podem ser encontrados relativamente a essa conjugação entre textos, condições de produção de leituras e contextos diferenciados. A personagem Antonio José Bolívar, protagonista do livro $O$ velho que lia romances de amor, de Luís Sepúlveda (2000), ao ler, no meio da Floresta Amazônica, no Brasil, um romance cujo cenário centrase na cidade de Veneza, na Itália, logo ressemantiza os referentes desconhecidos, relação apresentada no excerto que se segue: Ao chegar a hora da sesta tinha lido e reflectido umas quatro páginas, e estava incomodado com a sua incapacidade de imaginar Veneza com as características atribuidas a outras cidades também descobertas nos romances...A palavra "gôndola" conseguiu acabar por seduzi-lo, e pensou em chamar assim à sua canoa. A Gôndola do Nangaritza (idem: 65). 
de seus negócios, que, no anonimato do espaço tecnocraticamente arquitetado, constróem "frases imprevisíveis, trilhas em parte ilegíveis” (Certeau, idem: 45). Uma construção anônima que, embora composta por elementos assimilados da ordem cultural dominante, desenha "as astúcias de interesses outros e de desejos que não são nem determinados nem captados pelos sistemas onde se desenvolvem" (idem: ibiden). Assim, no entender deste autor, se, no relacionamento com os consumidores, os produtores dispõem de estratégias para gerir seus interesses, no lado oposto, os cidadãos receptores, produtores desconhecidos, utilizam-se de táticas para jogar com e contra as forças hegemônicas. Deste modo, são as operações e os usos individuais e coletivos, as trajetórias variáveis dos praticantes que dimensionam a cultura como (re)apropriação e o consumo e a recepção, por sua vez, como maneiras de praticar, artes de fazer.

Essa possível convergência teórica que, consideradas as linhas de pensamento, tracejam-se entre o modelo proposto por Hall e os pressupostos defendidos por Certeau parece, com efeito, balizar a necessidade de as pesquisas de recepção midiática ponderarem os usos, as satisfações e os processos de decodificação múltiplos e diferenciados dos receptores, não negligenciado os contextos sócio-históricos e culturais que integram e matizam essas práticas cotidianas. No que concerne aos percursos metodológicos trilhados nas investigações sobre as audiências ativas, têm sido frequentes as abordagens de cunho quantitativo e qualitativo, sendo que muitas pesquisas têm valorizado o cruzamento de ambas as perspectivas (Jensen \& Jankowski, 1993; Lopes, 1997). Importa-nos referir, no entanto, que, como um dos desafios dos Estudos Culturais tem sido agregar em seus estudos as envolvências históricas, culturais e institucionais circundantes aos sujeitos receptores - considerando que as historicidades são preponderantes aos modos como os cidadãos apropriam-se dos produtos simbólicos -, as perspectivas qualitativas vêm, comumente, sendo as mais exploradas, incidindo em métodos de análises textuais e discursivas, aplicações de entrevistas em profundidade e etnografias de audiência ${ }^{7}$.

Como demonstram Jensen \& Jankowski (idem), as abordagens qualitativas objetivam compilar informações que sejam difíceis de serem expressas numericamente, nomeadamente aquelas reveladoras de desejos, medos, crenças e percepções dos grupos pesquisados. Todavia, se, por um lado, essa perspectiva possibilita compreender as causas e motivações, concretas e/ou imaginárias, inerentes às ações coletivas, por outro lado, apresenta a impossibilidade de se generalizar os resultados auferidos. Daí a complementaridade com a perspectiva quantitativa, que, embora deva ser ponderada casuísticamente, fornece informações

${ }^{7}$ Segundo Hartley (2004), as etnografias de audiência originam das abordagens antropológicas e envolvem a integração do investigador num determinado grupo, objetivando (re)conhecer as escolhas midiáticas e culturais e os comportamentos partilhados pelos membros do grupo. 
mensuráveis, indicadoras de tendências e padrões particulares. A delimitação do viés metodológico, em suma, deve ser claramente consentânea aos objetivos gerais e específicos da investigação. $\mathrm{O}$ que, de fato, não se pode descurar é que produção e recepção comunicativa, como processos indissociáveis, afloram e ocultam sentidos para além do que "olhares" simplistas conseguem captar.

\section{Dos meios às mediações: "olhares" latino-americanos}

Neste trajeto reflexivo, demonstramos que os Estudos Culturais britânicos facultam-nos pistas para pensarmos as relações entre comunicação e cultura, de modo que as múltiplas maneiras de praticar dos consumidores/receptores não sejam negligenciadas em nossas análises. O postulado-base dessa vertente científica assegura que os receptores são sujeitos sociais dotados de variadas competências de leitura, que os permitem relacionar-se diversificadamente com os produtos e discursos das indústrias culturais.

Se retomarmos, então, a problemática alusiva aos modos como os sujeitos lêem as ideologias e outros textos propagados pelos veículos de comunicação, logo depreendemos que há complexos percursos de leitura, de apropriações e interpretações possíveis, dependentes de variáveis emergentes nos processos de decodificação do texto/discurso. Como demonstra Hall (op. cit.), assim como as leituras podem divergir em relação àquelas propostas no ato da codificação textual - dissonância proveniente de expectativas, conhecimentos e universo de valores diferenciados dos receptores frente ao que lhes é apresentado -, também podem sintonizar-se com as leituras sugestionadas pelo enunciador, o que não significa que tal reciprocidade implique qualquer relação de passividade e alienação dos leitores, mas, pelo contrário, seja fruto de constante negociação interpretativa. Relativamente a esse propósito, consideramos fundamental questionar quais os elementos estruturais contidos no texto, ou que lhes são externos, que servem de eixos de convergência entre as pressuposições da mídia (e, inclusive, do mercado) e as múltiplas competências de leitura dos receptores. Em outras palavras, que fatores nodais possibilitam a composição de "lugares de encontro" entre interesses, à primeira vista, distintos?

Radicada nos Estudos Culturais britânicos, a vertente científica latino-americana desenvolvida no campo das Ciências da Comunicação também nos propicia subsídios teóricos para compreender a estreita relação entre os meios de comunicação e as audiências plurais, ou melhor, entre a mídia e as distintas matrizes culturais. Tendo como problemática central as novas configurações da cultura popular na América Latina, desencadeadas a partir da emergência das indústrias culturais no sistema capitalista da
A vertente latinoamericana das Ciências da Comunicação nos propicia subsídios teóricos para compreender a relação entre os meios de comunicação e as audiências plurais 
segunda metade do século XX, esses estudos procederam a um repensar dos processos comunicativos, contribuindo para com a mudança paradigmática que, desde a década de 80 , se vem sucedendo nesse campo científico americano.

Como demonstra Escosteguy (2001), apesar das singularidades que caracterizaram o desenvolvimento dos Estudos Culturais nessa região, existe afinidade entre o corpo teórico-metodológico de análise cultural britânica com as investigações latinoamericanas, uma vez que ambas as vertentes problematizam a inserção das indústrias culturais no tecido social. Acresce que, tendo em conta que a América Latina abarca heterogeneidades culturais, pluralidades étnicas, diversidades econômicas e, de fato, um contexto social bastante diferenciado frente ao da GrãBretanha, as investigações latino-americanas adotaram contornos peculiares, enfatizando a análise historicamente consentânea a esse contexto cultural híbrido (Canclini, 2001). Sendo assim, e como demonstram Escosteguy \& Jacks (2003), mais do que a uma questão simplesmente geográfica, a metodologia dessses estudos diz respeito a um "posicionamento a partir do qual se pensa politicamente, isto é, entende a comunicação como um espaço estratégico para pensar as contradições das sociedades latino-americanas" (Escosteguy \& Jacks, idem: s/p).

Nesse sentido, esse movimento acadêmico-intelectual focaliza, no plano teórico, as correspondências entre comunicação e cultura, mas relativizando a primeira a partir da última, ou melhor, concebendo os processos comunicativos e culturais como fenômenos integrantes às práticas cotidianas. Deste modo, descentraliza as análises isoladas sobre os veículos de comunicação e seus conteúdos, isto é, os meios, para evidenciar as matrizes culturais e as mediações que configuram a existência das culturas massivas e dos meios-tecnologias (Martín-Barbero, 1997, 2002; Martín-Barbero \& Rey, 2001).

$\mathrm{Na}$ acepção de Martín-Barbero (idem), um dos expoentes desse movimento latino-americano, é preciso desenvolver outros parâmetros de estudo acerca dos meios de comunicação, de modo que os processos comunicativos sejam (re)pensados a partir das práticas socioculturais, das transformações e experiências do dia-a-dia dos sujeitos e grupos. Segundo este autor, faz-se necessário ultrapassar a concepção de que tais processos sejam estruturados de forma regular, unidimensional, fundamentados no paradígma produção/mensagem/recepção, para perspectivá-los como um sistema multifacetado e cíclico. A recepção, segundo esses "olhares" latino-americanos, configura-se como uma atividade viva e criativa, como um lugar novo. Na base do pensamento de Martín-Barbero e de demais investigadores que constituem essa vertente científica - como Canclini, González, Orozco e outros -, defende-se que não são apenas mensagens que circulam nos meios
A recepção, segundo esses "olhares" latinoamericanos, configura-se como uma atividade viva e criativa, como um lugar novo 
maciços de comunicação, assim como não são de efeitos e reações que se compõem o ato comunicativo, mas de textos e de competências de leitura diferenciadas, ativadas aquando da recepção dos bens simbólicos.

Tal como demonstrado no modelo proposto por Hall, essa vertente de pensamento e pesquisa também reconhece o peso da cultura nas transações produtoras de sentidos sobre os textos midiáticos. Mas o "olhar" latino-americano identifica, inclusive, a atuação de instâncias mediadoras entre os dois extremos do processo comunicativo: os veículos de comunicação e os sujeitos receptores. Assim, as mediações seriam as responsáveis pelas variações de postura frente aos bens simbólicos, uma vez que "constituem um conjunto de fatores que estrutura, organiza e reorganiza a percepção e apropriação da realidade, por parte do receptor" (Britos, op. cit.: 4).

Com a finalidade de estabelecer critérios teóricos e metodológicos para os estudos sobre os usos sociais dos dispositivos midiáticos, especialmente sobre a recepção televisiva, Martín-Barbero (1997) propõem três dimensões, ou melhor, três lugares onde se estruturam as mediações: a cotidianidade familiar, a temporalidade social e a competência cultural. Resumidamente, o cotidiano, lugar privilegiado para abordar o processo de recepção, é onde ocorre a captação do real, onde os sujeitos sociais se relacionam com as múltiplas dimensões de sua vida, atribuindo significados a cada uma delas. As dinâmicas familiares, as trajetórias de vida individuais e coletivas, os haveres e saberes, os medos e desejos compartilhados ou recalcados constituem fatores propulsores dos movimentos cotidianos, das instâncias mediadoras e, portanto, das práticas receptivas.

A temporalidade social, por sua vez, refere-se à especificidade do tempo cotidiano, que, diferentemente do tempo produtivo, é cíclico, repetitivo e fragmentado, como o tempo organizado pela mídia, nomeadamente pela televisão. Por fim, a competência cultural referese aos repertórios adquiridos tanto via educação formal quanto a partir das pertenças a um grupo social, como as culturas regionais, os dialetos locais e as distintas mestiçagens urbanas. São competências transmitidas, reconfiguradas e vivificadas nas memórias e nos imaginários coletivos e com base nas quais "projetam sua identidade os homens e as mulheres, os adultos e os jovens, os indígenas e os negros, os camponeses, os habitantes da cidade" (Martín-Barbero, 2002: 175). São, em suma, esses lugares de mediação que, segundo Martín-Barbero, permitem a identificação dos sujeitos sociais com as narrativas midiáticas, possibilitando o drama do reconhecimento dos receptores com as identidades individuais e coletivas que se espraiam, em especial, nas telas da televisão.

Leal (1986), num dos primeiros trabalhos desenvolvidos com base nos postulados teórico-metodológicos dos estudos da recepção e das mediações, assinala que o ato de assistir à televisão pressupõe a ativação de condições de produção de leituras, que são articuladas 
pelas mediações. Esta autora chegou à conclusão que as mediações se diferenciam entre os grupos sociais, mas se assemelham entre grupos com características similares, como as relativas ao gênero, ao estatuo social, à idade, ao nível de escolaridade, dentre outras variáveis. Em sua pesquisa sobre a recepção de telenovelas, Leal afirma que "a eficácia da mensagem estaria comprometida se o argumento da novela não se organizasse em uma narrativa que dissesse respeito a estes afetos e a todo um sistema de crenças e valores sociais" (Leal, idem: 86).

Da mesma forma, Lopes et. al. (2002), ao desenvolver o projeto de pesquisa sobre a recepção da telenovela brasileira, propõe um protocolo metodológico para o estudo e a interpretação das mediações no gênero ficcional televisivo. Para além dos lugares de mediações propostos por Martín-Barbero, esta autora tipifica as seguintes instâncias mediadoras: a subjetividade, que abarca a esfera da intimidade individual, remetendo ao intercâmbio entre o sujeito e a cultura, ou seja, entre o self, o imaginário e o ambiente social; a videotécnica, referente aos nexos entre a recepção e os artifícios técnicos utilizados pelos produtores na construção do texto televisivo; os gêneros ficcionais, como matrizes culturais portadoras de referenciais comuns de mediação entre produtores culturais, bens simbólicos e receptores, isto é, como características e valores arraigados nas culturas e imaginários sociais contemporâneos.

Assim, repensar os processos comunicativos deslocando o "olhar" para as mediações, e suas intrínsecas confluências com os meios, ou seja, articular comunicação e cultura como indissociáveis da prática social cotidiana, requer problematizar as representações e ideologias enaltecidas pelos meios de comunicação. Principalmente a televisão, "cenário cotidiano das mais secretas perversões do social e também da constituição de imaginários coletivos" (MartínBarbero, 2001: 26), pode ser concebida como o locus privilegiado onde as matrizes culturais se fazem presentes, ou o meio onde os diferentes grupos expressam e legitimam seus desejos e medos, suas exigências, frustrações e percepções das realidades. É nesse sentido que Martín-Barbero (idem) afirma que a capacidade de mediação da televisão resulta menos do aparato tecnológico e da modernização de seus formatos do que das expectativas sociais e culturais ante esse referente midiático. Equivale dizer que não são os conteúdos que convocam as pessoas para a prática da televidência (Orozco, 2001), senão os contextos socioculturais que as impelem ao diálogo com a televisão, pois se "a televisão atrai é porque a rua expulsa, é dos medos que vivem os meios" (Martín-Barbero, 2001: 40).

Para concluirmos, importa-nos retomar as reflexões apresentadas anteriormente, no intuito de salientarmos que, no processo da recepção midiática, afloram-se as matrizes culturais, as subjetividades, as representações e sentidos que transitam nas memórias
Articular comunicação e cultura, como indissociáveis da prática social cotidiana, requer problematizar as representações e ideologias enaltecidas pelos meios de comunicação 
e imaginários coletivos. Estes são, certamente, elementos indicadores de História e Cultura, que influem de forma ativa nos inter-relacionamentos entre textos midiáticos e sujeitos receptores. Ainda que as leituras empreendidas pelos cidadãos convirjam com as leituras preferenciais dos meios de comunicação massiva, compartilhando clarividências de ideologias enaltecidas no decurso dos tempos, acreditamos, tal como Hall e Certeau, nas negociações desencadeadas no ato de ler e usar os bens simbólicos.

Mas também é possível invertermos o prisma através do qual buscamos analisar o processo da recepção midiática. A vertente latinoamericana dos Estudos Culturais é bastante categórica ao certificar que os processos comunicativos encontram-se estritamente vinculados aos dinamismos culturais e que as diferentes mediações configuram o entorno significante, a matriz de sentidos que alimenta o processo da recepção, e inclusive o da produção. Pensar a comunicação a partir da cultura, deslocando, portanto, o lugar desde onde se questiona essa relação, leva-nos a considerar que, no bojo das narrativas midiáticas, não transitam apenas estratégias discursivas de interesses políticos e econômicos locais e transnacionais. Para além desta constatação, são conhecimentos sociocêntricos ${ }^{8}$, enredos históricos e culturais que dimensionam "lugares de encontro" entre duas arenas efetivamente interdependentes: comunicação e cultura.

\section{Referências}

ÁLVARES, Cláudia \& SILVEIRINHA, Maria J. "Introdução à Mesa Temática Estudos Culturais e de Género". In Livro de Actas do $4^{\circ}$ Congresso da Associação Portuguesa de Ciências da Comunicação (SOPCOM). Aveiro: Comissão Editorial da Universidade de Aveiro, 2005.

ARRUDA, Ângela. "As representações sociais: desafios de pesquisa". In Revista das Ciências Humanas, Série especial, Temática: Representações Sociais: Questões Metodológicas, Centro de Filosofia e Ciências Humanas da Universidade Federal de Santa Catarina, Florianópolis, Editora da UFSC, 2002.

BRITTOS, Valério C. Comunicação e cultura: o processo de recepção. http:// www.bocc.ubi.pt/pag/brittos-valerio-Comunicacao-cultura.pdf. (Acedido em Fevereiro de 2006).

CANCLINI, Nestor G. La Globalización Imaginada. Buenos Aires: Paidós, 2001.

CERTEAU, Michel de. A invenção do cotidiano: 1. Artes de fazer. Trad. de Ephraim Ferreira Alves. Petrópolis: Vozes, 1994.

CUNHA, Isabel F. Comunicação e culturas do quotidiano. Lisboa: Quimera, 2002 .

ESCOSTEGUY, Ana C. D. Cartografias dos estudos culturais: uma versão latino-americana. Coleção Estudos Culturais. Belo Horizonte: Autêntica, 2001.

\& Jacks, NILDA, A. "Objeções à associação entre estudos culturais e

${ }^{8}$ Os conhecimentos sociocêntricos (Arruda, 2002), estudados principalmente no campo da Psicologia Social, atendem às aspirações, aos interesses, aos medos e desejos do grupo. 
folkcomunicação". In Verso e reverso: revista da comunicação, $n^{\circ} 37$, Ano XVII, 2003. http://www.versoereverso.unisinos.br/index.php?e=1\&s=9\&a=10 (Acedido em Fevereiro de 2006).

HALL, Stuart. Da diáspora: identidades e mediações culturais. Organização Liv Sovik. Tradução Adelaide La Guardiã Resende et. al. Belo Horizonte: Editora UFMG; Brasília: Representação da UNESCO no Brasil, 2003.

HARTLEY, John. Comunicação, Estudos Culturais e Media: conceitos-chave. Trad. Fernanda Oliveira. Lisboa: Quimera, 2004.

JENSEN, K. B. \& JANKOWSKI, N. W. (eds.). Metodologias caulitativas de investigacion en comunicacion de masas. Barcelona: Bosh, 1993.

LEAL, Ondina F. A leitura social da novela das oito. Petrópolis: Vozes, 1986.

LOPES, Maria I. V. Pesquisa em comunicação. $3^{a}$ edição. São Paulo: Loyola, 1997.

et. al. Vivendo com a telenovela: mediações, recepção, teleficcionalidade. São Paulo: Summus, 2002.

MARTÍN-BARBERO, Jesús. Dos meios às mediações: comunicação, cultura e hegemonia. Trad. Ronald Polito e Sérgio Alcides. Rio de Janeiro: Editora UFRJ, 1997.

Ofício de cartógrafo. Travessias latino-americanas da comunicação na cultura. Tradução de Fidelina González. São Paulo: Edições Loyola, 2002.

\& Rey, Germán. Os exercícios do ver: hegemonia audiovisual e ficção televisiva. Trad. Jacob Gorender. São Paulo: SENAC, 2001.

MATTELART, Armand \& MATTELART, Michele. História das teorias da comunicação. $2^{\text {a }}$ edição. Porto: Campo das Letras, 2002.

MCQUAIL, Denis. Teoria da comunicação de massas. Lisboa: Fundação Calouste Gulbenkian, 2003.

NIGHTINGALE, Virgínia. El estudio de las audiencias. El impacto de lo real. Barcelona: Paidós Comunicación, 1999.

OROZCO, Guillermo. Televisión, Audiências y Educación. Buenos Aires: Norma, 2001.

POLISTCHUK, Llana \& TRINTA, Aluizio R. Teorias da comunicação: o pensamento e a prática da Comunicação Social. Rio de Janeiro: Campus, 2003. TURNER, Lynn H. \& WEST, Richard. Teoría de la comunicación. Análisis y Aplicación. Madrid: McGRAW-HILL, 2005.

WOLF, Mauro. Teorias da comunicação. Tradução de Maria Jorge Vilar de Figueiredo. 9a edição. Lisboa: Editorial Presença, 2006.

Recebido em 20 de outubro de 2008. Aprovado em 4 de abril de 2009. 